\title{
KEEFEKTIFAN DOSIS TEPUNG BIJI SRIKAYA (Annona squamosa L.) DALAM MENGENDALIKAN HAMA BUBUK KEDELAI (Callosobruchus analis F.) DI PENYIMPANAN
}

\section{The Effectiveness Dose of Custard Apple Seed Flour (Annona squamosa L.) to Control Callosobruchus analis F. in Storage}

\author{
Rahmiyul Insani dan Desita Salbiah \\ Program Studi Agroteknologi, Fakultas Pertanian, Universitas Riau \\ Email: rahmiyulins@gmail.com HP : 082386446835 \\ [Diterima: Februari 2021; Disetujui: April 2021]
}

\begin{abstract}
Soybean is an important food crop in Indonesia, which contains a lot of protein and is useful as an industrial ingredient and animal feed. Callosobruchus analis F. is a pest that causes a decrease in soybean production in storage. The suggestion recommended is to use plant based insecticides by using custard apple seed (Annona squamosa L.). This research aims to obtain a dose of custard apple seed flour (Annona squamosa) that is effective in controlling soy pest Callosobruchus analis in stored soybean seeds. The research was conducted at the Plant Pest Laboratory of Faculty of Agriculture, Riau University, from July to October 2019. The study was carried out using a completely randomized design with 6 treatments and 4 replications. The dose treatment of custard apple seed flour was given to each experimental unit was 0 g. $100 \mathrm{~g}^{-1}$ soybean seeds, $2 \mathrm{~g} .100 \mathrm{~g}^{-1}$ soybean seeds, $4 \mathrm{~g} .100 \mathrm{~g} \mathrm{~g}^{-1}$ soybean seeds, 6 g. $100 \mathrm{~g}^{-1}$ soybean seed, 8 g. $100 \mathrm{~g} \mathrm{~g}^{-1}$ soybean seed and $10 \mathrm{~g} .100 \mathrm{~g} \mathrm{~g}^{-1}$ soybean seed. The results showed that the provision of custard apple seed flour at a dose of $4 \mathrm{~g} .100 \mathrm{~g} \mathrm{~g}^{-1}$ of soybean seeds was effective in killing $C$. analis pests. This could cause a total mortality of $80 \%$ with early death of 14.50 hours after application and LT50 34.00 hours after application with an individual increase of 19.25 C. analis pests with a percentage of weight depreciation of soybean seeds of $1.93 \%$.
\end{abstract}

Keywords: Soybeans, Callosobruchus analis, Custard Apple Seed, Botanical Insecticide, Dosage

\begin{abstract}
ABSTRAK
Kedelai adalah tanaman pangan penting di Indonesia, yang mengandung banyak protein dan berguna sebagai bahan industry dan pakan ternak. Callosobruchus analis $\mathrm{F}$. adalah hama yang menyebabkan penurunan produksi kedelai dalam penyimpanan. Pengendalian yang disarankan adalah menggunakan insektisida nabati yang menggunakan biji srikaya (Annona squamosa L.). Penelitian ini bertujuan untuk mendapatkan dosis tepung biji srikaya (Annona squamosa) yang efektif dalam mengendalikan hama kedelai Callosobruchus analis pada biji kedelai di penyimpanan. Penelitian ini dilaksanakan di Laboratorium Hama Tumbuhan Fakultas Pertanian Universitas Riau, mulai dari bulan Juli sampai Oktober 2019. Penelitian dilaksanakan secara eksperimen menggunakan rancangan acak lengkap (RAL) dengan 6 perlakuan dan 4 ulangan. Perlakuan dosis yang tepung biji srikaya yang diberikan untuk setiap unit percobaan adalah 0 g. $100 \mathrm{~g}^{-1}, 2$ g. $100 \mathrm{~g}^{-1}, 4$ g. $100 \mathrm{~g}^{-1}, 6$ g. $100 \mathrm{~g}^{-1}, 8 \mathrm{~g}$. $100 \mathrm{~g}^{-1}$ dan 10 g. $100 \mathrm{~g}^{-1}$ biji kedelai. Hasil penelitian menunjukkan bahwa pemberian tepung biji srikaya dosis 4 g. $100 \mathrm{~g}^{-1}$ biji kedelai efektif dalam mengendalikan hama $C$. analis. Hal ini menyebabkan mortalitas total sebesar $80 \%$, waktu awal kematian selama 14.50 jam setelah aplikasi dan $\mathrm{LT}_{50} 34$ jam setelah aplikasi yang mana jumlah keturunannya sebanyak 19.25 ekor dengan persentase penyusutan berat biji kedelai sebesar $1.93 \%$.
\end{abstract}

Kata kunci: Biji Kedelai, Callosobruchus analis, Biji Srikaya, Pestisida Nabati, Dosis.

\section{PENDAHULUAN}

Kedelai merupakan tanaman pangan penting di Indonesia sebagai bahan makanan yang mengandung protein nabati dan berguna sebagai bahan industri dan pakan ternak. Menurut Badan Pusat Statistik Riau (2017) 
bahwa produksi kedelai di Provinsi Riau pada tahun 2017 mengalami penurunan dari tahun sebelumnya. Penurunan produksi ini dapat disebabkan oleh hama di penyimpanan yaitu Callosobruchus analis $\mathrm{F}$.

Serangan hama ini dapat menyebabkan biji kedelai di penyimpanan menjadi rusak dan tidak dapat dikonsumsi atau dijadikan benih. Besar kecilnya tingkat kerusakan yang disebabkan oleh hama ini ditentukan dari perkembangan, kepadatan populasi dan serangan hama (Herminanto et.al, 2010). Menurut Suyono (1988) kerusakan yang disebabkan oleh hama C.analis di penyimpanan dapat mencapai 7998\%.

Pengendalian di penyimpanan biasanya dilakukan secara kimia, dengan fumigasi tempat penyimpanan. Pengendalian hama dengan cara tersebut memang dapat berhasil dengan cepat, namun cara ini dapat menimbulkan efek negatif seperti menyebabkan pencemaran lingkungan, dan membahayakan konsumen (Harinta, 2009). Alternatif lebih aman yaitu penggunaan insektisida nabati yang berasal dari tanaman.Wowiling (2010) mengungkapkan bahwa insektisida nabati apabila diaplikasikan akan membunuh hama dan residunya cepat menghilang di alam. Jenis tanaman yang bisa digunakan sebagai insektisida nabati adalah tanaman srikaya (Annona squamosa L.).

Bagian dari tanaman srikaya (A. squamosa) yang dapat dijadikan sebagai insektisida nabati adalah bijinya. Menurut Kardinan (2002), biji srikaya (A. squamosa) mengandung senyawa kimia annonain dan squamosin (golongan asetogenin) yang dapat berperan sebagai insektisida, larvasida, repellent dan antifeedant yang bersifat racun terhadap serangga dengan cara masuk sebagai racun kontak dan racun perut, dan cara kerjanya di dalam tubuh hama adalah sebagi racun syaraf dan racun perncernaan. Menurut hasil penelitian Sinaga (2010) menunjukkan bahwa perlakuan serbuk biji srikaya dengan dosis 2,5 g. $100^{-1} \mathrm{~g}$ kacang hijau menyebabkan mortalitas Callosobruchus chinensis mencapai 100\%. Hal ini sesuai dengan pendapat Dadang dan Prijono (2008) insektisida dikatakan efektif apabila mampu mematikan serangga hama besar atau sama dengan $80 \%$.

Berdasarkan hal tersebut peneliti telah melaksanakan penelitian dengan judul "Keefektifan Dosis Tepung Biji Srikaya (Annona squamosa L.) dalam Mengendalikan Hama Bubuk Kedelai (Callosobruchus analis F.) di
Penyimpanan". Penelitian ini bertujuan untuk mendapatkan dosis tepung biji srikaya (Annona squamosa) yang efektif dalam mengendalikan hama bubuk kedelai (Callosobruchus analis) pada biji kedelai di penyimpanan.

\section{METODOLOGI PENELITIAN}

Penelitian telah dilaksanakan di Laboratorium Hama Tumbuhan Fakultas Pertanian Universitas Riau. Penelitian dilaksanakan selama tiga bulan dari bulan Juli sampai September 2019.

Bahan yang digunakan adalah imago $C$. analis, biji kedelai varietas DETAM 3 dan biji srikaya (A. squmosa). Alat yang digunakan dalam penelitian ini adalah stoples plastik ukuran panjang $20 \mathrm{~cm}$, tinggi $5 \mathrm{~cm}$, dan lebar $13 \mathrm{~cm}$, insec net, timbangan analitik, gunting, mesin penggiling, termohygrometer, kertas label, aspirator, isolasi, kertas tissue kasar, kamera dan alat tulis.

Penelitian dilakukan secara eksperimen dengan menggunakan rancangan acak lengkap (RAL) dengan enam perlakuan dan empat ulangan yang terdiri dari 2 seri sehingga diperoleh 48 unit percobaan. Setiap unit percobaan diinfestasikan sebanyak 10 ekor imago $C$. analis yang terdiri dari 5 ekor imago jantan dan 5 ekor imago betina, dengan jumlah biji kedelai pada setiap perlakuan sebanyak $100 \mathrm{~g}$ perstoples. Perlakuan yang diberikan adalah beberapa dosis tepung biji srikaya (A), yaitu 0 g. $100 \mathrm{~g}^{-1}, 2$ g. $100 \mathrm{~g}^{-1}, 4$ g. $100 \mathrm{~g}^{-1}, 6$ g. $100 \mathrm{~g}^{-1}, 8$ g. $100 \mathrm{~g}^{-1}$ dan 10 g. $100 \mathrm{~g}^{-1}$ biji kedelai.

Parameter pengamatan terdiri dari awal kematian (jam), lethal time 50 (jam), mortalitas harian, mortalitas total $(\%)$, penyusutan berat biji kedelai $(\%)$ dan jumlah keturunan $(\%)$. Data yang diperoleh dari hasil penelitian dianalisis secara statistik dan diuji lanjut dengan dengan menggunakan uji Beda Nyata Jujur (BNJ) pada taraf 5\%.

\section{HASIL DANPEMBAHASAN}

\section{Waktu Awal Kematian}

Hasil rata-rata waktu awal kematian $C$. analis setelah dilakukan uji BNJ pada taraf 5\% dapat dilihat pada Tabel 1.

Tabel 1 menunjukkan bahwa pemberian tepung biji srikaya dengan dosis 10 g.100 g $\mathrm{g}^{-1}$ biji kedelai dengan waktu awal kematian yaitu 4,25 jam adalah paling cepat mematikan hama C.analis dan berbeda nyata dengan dosis 
tepung biji srikaya 0 g.100 g $\mathrm{g}^{-1}, 2$ g.100 g $\mathrm{g}^{-1}, 4$ g.100 g $\mathrm{g}^{-1}, 6$ g.100 g $\mathrm{g}^{-1}$ dan 8 g.100 g $\mathrm{g}^{-1}$ biji kedelai dengan waktu awal kematian dengan kisaran waktu 9,75-96 jam. Hal ini diduga karena banyaknya senyawa asetogenin yang terkandung pada biji srikaya sehingga waktu yang dibutuhkan mematikan hama $C$. analis cepat. Sesuai dengan pernyataan Aminah (1995) dalam Rosmanto (2016) bahwa tinggi rendahnya suatu dosis akan mempengaruhi kandungan bahan aktif dan akan berpengaruh terhadap awal kematian serangga uji.

Tabel 1. Rata-rata Waktu Awal Kematian $C$. analis Setelah Pemberian Beberapa Dosis Tepung Biji Srikaya.

\begin{tabular}{cc}
\hline $\begin{array}{c}\text { Dosis tepung biji } \\
\text { srikaya }\end{array}$ & $\begin{array}{c}\text { Waktu awal kematian } \\
\text { (jam) }\end{array}$ \\
\hline 0 g. $100 \mathrm{~g} \mathrm{~g}^{-1}$ & $96,00 \mathrm{a}$ \\
$2 \mathrm{~g} .100 \mathrm{~g} \mathrm{~g}^{-1}$ & $16,00 \mathrm{~b}$ \\
$4 \mathrm{~g} .100 \mathrm{~g} \mathrm{~g}^{-1}$ & $14,50 \mathrm{~b}$ \\
$6 \mathrm{~g} .100 \mathrm{~g}^{-1}$ & $12,25 \mathrm{bc}$ \\
$8 \mathrm{~g} .100 \mathrm{~g}^{-1}$ & $9,75 \mathrm{c}$ \\
$10 \mathrm{~g} .100 \mathrm{~g}^{-1}$ & $4,25 \mathrm{~d}$ \\
\hline
\end{tabular}

Pemberian tepung biji srikaya dosis 6 g.100 $\mathrm{g}^{-1}$ biji kedelai berbeda tidak nyata dengan dosis 8 g. $100 \mathrm{~g}^{-1}, 4$ g. $100 \mathrm{~g}^{-1}$ dan 2 g. $100 \mathrm{~g}^{-1}$ biji kedelai dan berbeda nyata dengan dosis 10 g. $100 \mathrm{~g}^{-1}$ dan 0 g. $100 \mathrm{~g}^{-1}$ biji kedelai. Hal ini menunjukkan bahwa peningkatan dosis tepung biji srikaya dari 2 g. $100 \mathrm{~g}^{-1}$ ke 4 g.100 $\mathrm{g}^{-1}$ dan 6 g.100 $\mathrm{g}^{-1}$ biji kedelai belum memberikan perbedaan yang nyata terhadap waktu awal kematian, diduga bahwa hama $C$. analis masih memberikan respon yang sama terhadap senyawa aktif yang terkandung dalam tepung biji srikaya sehingga peningkatan dosis yang diberikan berbeda tidak nyata dalam mematikan hama $C$. analis. Hal ini sesuai dengan pendapat Dadang dan Prijono (2008) yang menyatakan bahwa suatu serangga memiliki kepekaan terhadap senyawa bioaktif yang dapat mempengaruhi kemampuan serangga dalam menyingkirkan dan menguraikan bahan racun dari tubuhnya.

\section{Lethal Time 50}

Hasil rata-rata Lethal time $50 \mathrm{C}$. analis setelah dilakukan uji BNJ pada taraf 5\% dapat dilihat pada Tabel 2.

Tabel 2 menunjukkan bahwa waktu yang dibutuhkan tepung biji srikaya dalam mematikan 50\% hama $C$. analis pada dosis 10 g. $100 \mathrm{~g}^{-1}$ biji kedelai cenderung lebih cepat dibandingkan dengan dosis lain yakni selama
23,50 jam setelah aplikasi. Pemberian tepung biji srikaya dosis 10 g.100 g ${ }^{-1}$ biji kedelai berbeda tidak nyata dengan dosis $8 \mathrm{~g} .100 \mathrm{~g}^{-1}$ biji kedelai dengan waktu yang dibutuhkan mematikan 50\% hama selama 27,25 jam dan berbeda nyata dengan dosis 6 g.100 g g 4 g.100 g $\mathrm{g}^{-1}, 2$ g.100 g $\mathrm{g}^{-1}$ dan 0 g.100 g $\mathrm{g}^{-1}$ biji kedelai dengan masing-masing waktu yang dibutuhkan mematikan $50 \%$ hama yaitu 32,75 jam, 34,00 jam, 39,25 jam dan 96,00 jam. Pemberian tepung biji srikaya dosis 8 g. $100 \mathrm{~g}^{-1}$ biji kedelai membutuhkan waktu mematikan $50 \%$ hama $C$. analis selama 27,25 jam berbeda tidak nyata dengan dosis 10 g. $100 \mathrm{~g}^{-1}, 6$ g.100 $\mathrm{g}^{-1}$ dan 4 g.100 $\mathrm{g}^{-1}$ biji kedelai namun berbeda nyata dengan perlakuan $2 \mathrm{~g} .100 \mathrm{~g}^{-1}$ dan $0 \mathrm{~g} .100$ $\mathrm{g}^{-1}$ biji kedelai. Sesuai dengan pernyataan Dadang dan Prijono (2008) bahwa serangga memiliki kepekaan terhadap senyawa bioaktif dapat dipengaruhi oleh kemampuan metabolik serangga yang dapat menyingkirkan dan menguraikan bahan racun dari tubuhnya.

Tabel 2. Rata-rata $\mathrm{LT}_{50} \quad C$. analis Setelah Pemberian Beberapa Dosis Tepung Biji Srikaya.

\begin{tabular}{cc}
\hline $\begin{array}{c}\text { Dosis tepung biji } \\
\text { srikaya }\end{array}$ & Lethal time 50 (jam) \\
\hline 0 g. $100 \mathrm{~g}^{-1}$ & $96,00 \mathrm{a}$ \\
2 g. $100 \mathrm{~g}^{-1}$ & $39,25 \mathrm{~b}$ \\
$4 \mathrm{~g} .100 \mathrm{~g}^{-1}$ & $34,00 \mathrm{bc}$ \\
6 g. $100 \mathrm{~g}^{-1}$ & $32,75 \mathrm{bc}$ \\
8 g. $100 \mathrm{~g}^{-1}$ & $27,25 \mathrm{~cd}$ \\
$10 \mathrm{~g} .100 \mathrm{~g}^{-1}$ & $23,50 \mathrm{~d}$ \\
\hline
\end{tabular}

Pemberian tepung biji srikaya dosis 6 g.100 g $\mathrm{g}^{-1}$ dan 4 g.100 $\mathrm{g}^{-1}$ biji kedelai membutuhkan waktu mematikan $50 \%$ hama $C$. analis selama 32,75 jam dan 34,00 jam berbeda tidak nyata dengan pemberian tepung biji srikaya dosis 2 g. $100 \mathrm{~g}^{-1}$ dan 8 g. $100 \mathrm{~g}^{-1}$ biji kedelai namun berbeda nyata dengan dosis 0 g.100 g $\mathrm{g}^{-1}$ dan 10 g. $100 \mathrm{~g}^{-1}$ biji kedelai. Pemberian tepung biji srikaya dosis 2 g. $100 \mathrm{~g}^{-1}$ biji kedelai mematikan $50 \%$ hama $C$. analis selama 39,25 jam berbeda tidak nyata dengan pemberian tepung biji srikaya dosis $4 \mathrm{~g} .100 \mathrm{~g}^{-1}$ dan 6 g.100 g ${ }^{-1}$ biji kedelai namun berbeda nyata dengan dosis 0 g. $100 \mathrm{~g}^{-1}, 8 \mathrm{~g} .100 \mathrm{~g}^{-1}$ dan 10 g. $100 \mathrm{~g}^{-1}$. Hal ini diduga karena kandungan senyawa asetogenin yang terdapat dalam tepung biji srikaya rendah, sehingga pengaruh yang ditimbulkan dalam mematikan hama $C$. analis membutuhkan waktu yang lama. Sesuai dengan pendapat Harbone (1979) dalam Pasaribu (2017), menyatakan bahwa 
pemberian dosis yang rendah akan berpengaruh pada kematian hama yang semakin lama, karena daya kerja suatu pestisida nabati sangat ditentukan oleh besarnya dosis yang diberikan.

\section{Mortalitas Harian Callosobruchus analis}

Hasil pengamatan terhadap mortalitas harian $C$. analis setelah pemberian dosis tepung biji srikaya menunjukkan persentase kematian $C$. analis mengalami fluktuasi selama 4 hari penelitian dan puncak mortalitas terjadi pada hari ke dua dapat dilihat pada Gambar 2.

Gambar 2 menunjukkan bahwa pada hari pertama telah terjadi kematian $C$. analis pada pemberian tepung biji srikaya dosis 2 g. $100 \mathrm{~g}^{-1}, 4$ g. $100 \mathrm{~g}^{-1}, 6$ g. $100 \mathrm{~g}^{-1}, 8$ g. $100 \mathrm{~g}^{-1}$ dan 10 g.100 $\mathrm{g}^{-1}$ biji kedelai yaitu sebesar $27,5 \%, 30 \%, 27,5 \%, 35 \%, 42,5 \%$. Hal ini menunjukkan senyawa asetogenin yang terdapat dalam biji srikaya mampu membunuh hama $C$. analis dalam waktu yang cepat, sesuai dengan penelitian Leviana (2017), bahwa mortalitas imago C. maculatus pada perlakuan ekstrak biji A. squamosa meningkat seiring bertambahnya dosis ekstrak uji, mortalitas pada perlakuan ekstrak biji A. squamosa mulai tampak nyata sejak hari pertama atau pada 24 jam setelah perlakuan (JSP) dengan persentase mortalitas mencapai $80 \%$ pada dosis tertingginya $62.7 \mu \mathrm{g} / \mu \mathrm{l}$ dan terus meningkat hingga hari terakhir pengamatan.
Hasil penelitian menunjukkan bahwa pada hari kedua terjadi puncak kematian hama $C$. analis pada pemberian tepung biji srikaya dosis 2 g.100 g $\mathrm{g}^{-1}, 4$ g. $100 \mathrm{~g}^{-1}, 6$ g.100 g $\mathrm{g}^{-1}, 8$ g.100 $\mathrm{g}^{-1}$ dan 10 g.100 $\mathrm{g}^{1}$ kacang kedelai mampu mematikan hama $C$. analis sebesar $30 \%, 32,5 \%, 35 \%, 37,5 \%$ dan $45 \%$. Hal ini karena senyawa asetogenin yang terkandung dalam tepung biji srikaya bekerja dengan maksimal sehingga menyebabkan puncak kematian hama C.analis. Sesuai dengan pendapat Tarumingkeng (1992) bahwa bahan aktif pestisida nabati mampu meracuni hama dan bekerja secara aktif hingga 2-3 hari.

Mortalitas terendah ditunjukkan pada hari keempat, hal ini disebabkan senyawa asetogenin yang terkandung dalam tepung biji srikaya tidak dapat bekerja secara maksimal lagi dan jumlah hama $C$. analis sudah berkurang dari hari sebelumnya. Dadang dan Prijono (2008) menyatakan bahwa beberapa kekurangan insektisida nabati antara lain persistensi insektisida nabati rendah, bahkan terjadi penurunan efikasi yang cepat sehingga memerlukan aplikasi lebih sering agar serangga uji menurun populasinya.

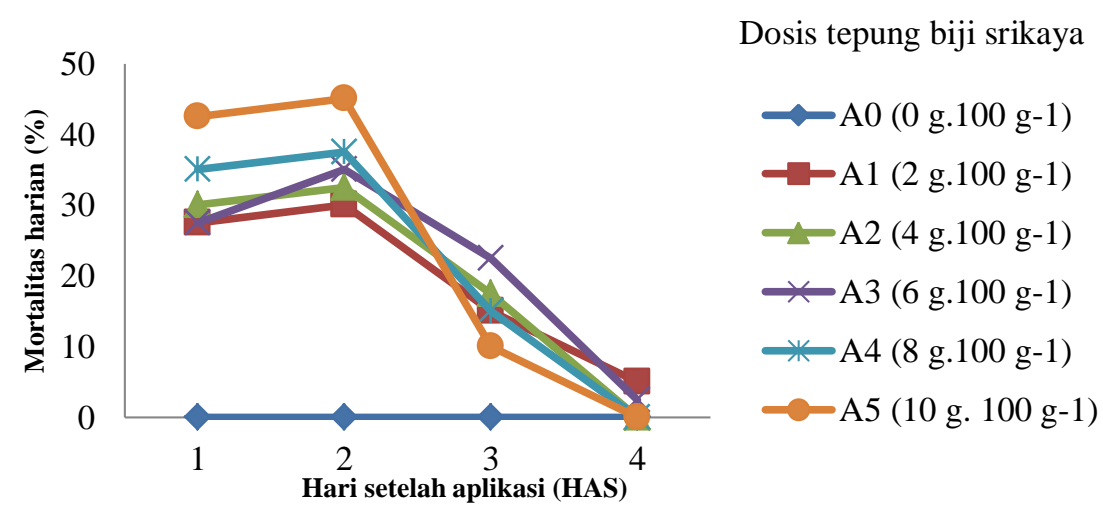

Gambar 2. Fluktuasi Mortalitas Harian C. analis Setelah Pemberian Beberapa Dosis Tepung Biji Srikaya.

\section{Mortalitas Total}

Hasil rata-rata mortalitas total $C$. analis setelah dilakukan uji BNJ pada taraf 5\% dapat dilihat pada Tabel 3. Tabel 3 menunjukkan bahwa mortalitas total hama $C$. analis tercepat pada tepung biji srikaya dosis $10 \mathrm{~g} .100 \mathrm{~g}^{-1}$ biji kedelai yang mampu mematikan hama $C$. analis sebesar $95 \%$ dan berbeda tidak nyata dengan dosis 8 g.100 $\mathrm{g}^{-1}$ dan 6 g. $100 \mathrm{~g}^{-1}$ biji kedelai dengan mortalitas total yaitu $87,50 \%$ namun berbeda nyata dengan dosis 4 g. $100^{\mathrm{g}-1}$, 2 g. $100 \mathrm{~g}^{-1}$ dan 0 g. $100 \mathrm{~g}^{-1}$ biji kedelai dengan mortalitas total masing-masing yaitu $80,00 \%$, $77,50 \%$ dan $0,00 \%$. Hal ini juga berkaitan dengan waktu awal kematian dan $\mathrm{LT}_{50}$ hama $C$. analis tercepat yaitu dengan waktu awal 
kematian 4,25 jam dan $\mathrm{LT}_{50} 23,50$ jam. Hal ini diduga bahwa semakin tinggi dosis tepung biji srikaya yang diberikan maka semakin meningkat persentase mortalitas total hama $C$. analis.

Tabel 3. Rata-rata Mortalitas Total C. analis Setelah Pemberian Beberapa Dosis Tepung Biji Srikaya.

\begin{tabular}{cc}
\hline $\begin{array}{c}\text { Dosis tepung biji } \\
\text { srikaya }\end{array}$ & Mortalitas total (\%) \\
\hline 0 g. $100 \mathrm{~g} \mathrm{~g}^{-1}$ & $0,0 \mathrm{c}$ \\
2 g. $100 \mathrm{~g}^{-1}$ & $77,5 \mathrm{~b}$ \\
4 g. $100 \mathrm{~g}^{-1}$ & $80,0 \mathrm{~b}$ \\
6 g. $100 \mathrm{~g}^{-1}$ & $87,5 \mathrm{ab}$ \\
8 g. $100 \mathrm{~g}^{-1}$ & $87,5 \mathrm{ab}$ \\
10 g. $100 \mathrm{~g} \mathrm{~g}^{-1}$ & $95,0 \mathrm{a}$ \\
\hline
\end{tabular}

Pemberian tepung biji srikaya dosis 4 g. $100 \mathrm{~g}^{-1}$ biji kedelai mampu mematikan $80 \%$ hama dan berbeda tidak nyata dengan dosis 8 g. $100 \mathrm{~g}^{-1}, 6$ g. $100 \mathrm{~g}^{-1}$ dan 2 g. $100 \mathrm{~g}^{-1}$ biji kedelai namun berbeda nyata dengan dosis 10 g. $100 \mathrm{~g}^{-1}$ dan 0 g. $100 \mathrm{~g}^{-1}$ biji kedelai. Hal ini disebabkan hama $C$. analis masih memberikan respon yang sama terhadap senyawa asetogenin yang terkandung di dalam tepung biji srikaya, namun pemberian tepung biji srikaya dosis 4 g.100 g $\mathrm{g}^{-1}$ biji kedelai telah efektif jika digunakan sebagai pestisida nabati dalam mengendalikan hama $C$. analis. Dadang dan Prijono (2008) juga berpendapat bahwa yang mengemukakan bahwa pestisida nabati dikatakan efektif apabila perlakuan tersebut dapat mengakibatkan kematian serangga uji besar atau sama dengan $80 \%$.

Tepung biji srikaya mengandung bahan aktif squamosin dan annonain yang termasuk golongan asetogenin dan dapat mempengaruhi mortalitas hama $C$. analis pada kedelai di penyimpanan. Subagiya et. al. (2018) menyatakan bahwa biji srikaya mengandung zat aktif annonain, squamosin, saponin, tannin, asimisin, alkaloid dan resin yang berdampak terhadap mortalitas hama Tribolium castaneum, pemberian dosis yang tinggi menyebabkan semakin tingginya tingkat mortalitas hama. Senyawa squamosin sebagai racun kontak, yang masuk melalui kulit (kutikula) dan ditransportasikan ke bagian tubuh serangga tempat pestisida aktif bekerja, setelah masuk ke dalam tubuh hama akan bekerja sebagai racun saraf dengan menghambat kerja enzim asetilkolinesterase.

Senyawa squamosin juga sebagai racun perut yang masuk melalui makanan yang dimakan oleh hama dengan cara kerja sebagai racun pencernaan. Pengaruh racun kontak dan racun perutterlihat dari gejala yang ditimbulkan hama C.analis yaitu pergerakan hama kurang aktif, berkurangnya nafsu makan, kejang-kejang yang ditandai dengan terbukanya kedua sayap serta tungkainya yang membengkok dan kemudian mati.

\section{Jumlah Keturunan $C$. analis (ekor)}

Hasil rata-rata jumlah keturunan $C$. analis setelah dilakukan uji BNJ pada taraf 5\% dapat dilihat pada Tabel 4.

Tabel 4. Rata-rata Jumlah Keturunan $C$. analis Setelah Pemberian Beberapa Dosis Tepung Biji Srikaya.

\begin{tabular}{cc}
\hline $\begin{array}{c}\text { Dosis tepung biji } \\
\text { srikaya }\end{array}$ & Jumlah keturunan (ekor) \\
\hline 0 g. $100 \mathrm{~g} \mathrm{~g}^{-1}$ & $101,50 \mathrm{a}$ \\
2 g. $100 \mathrm{~g}^{-1}$ & $21,50 \mathrm{~b}$ \\
4 g. $100 \mathrm{~g}^{-1}$ & $19,25 \mathrm{~b}$ \\
6 g. $100 \mathrm{~g} \mathrm{~g}^{-1}$ & $10,50 \mathrm{c}$ \\
8 g. $100 \mathrm{~g} \mathrm{~g}^{-1}$ & $9,50 \mathrm{c}$ \\
10 g. $100 \mathrm{~g}^{-1}$ & $6,25 \mathrm{c}$ \\
\hline
\end{tabular}

Tabel 4 menunjukkan bahwa pemberian tepung biji srikaya dengan dosis berbeda mampu menurunkan jumlah keturunan $C$. analis dan pemberian tepung biji srikaya dengan dosis $10 \quad$ g.100 $\mathrm{g}^{-1}$ biji kedelai menyebabkan jumlah keturunan hama $C$. analis rata-rata sebanyak 6,25 ekor dan berbeda nyata dengan dosis 4 g.100 g $\mathrm{g}^{-1}, 2$ g. $100 \mathrm{~g}^{-1}$ dan 0 g. $100^{-1}$ biji kedelai dengan jumlah keturunan hama $C$. analis masingmasing yaitu sebanyak 19,25 ekor, 21,50 ekor dan 101,50 ekor, namun berbeda tidak nyata dengan dosis 8 g.100 g $\mathrm{g}^{-1}$ dan 6 g.100 g ${ }^{-1}$ biji kedelai dengan jumlah keturunan hama $C$. analis masing-masing yaitu sebanyak 9,50 ekor dan 10,50 ekor. Hal ini diduga hama C.analis masih mampu mentolerir racun dari senyawa asetogenin, sehingga pertambahan dosis tidak memberikan pengaruh yang nyata terhadap jumlah keturunan $C$. analis. Dadang dan Prijono (2008) juga menyatakan bahwa suatu serangga memiliki kepekaan terhadap senyawa bioaktif yang dipengaruhi oleh kemampuan metabolik serangga yangg bisa menguraikan bahan racun dari tubuhnya.

Pemberian tepung biji srikaya dosis 4 g.100 $\mathrm{g}^{-1}$ biji kedelai menyebabkan jumlah keturunan hama $C$. analis sebanyak 19,25 ekor berbeda tidak nyata dengan pemberian tepung biji srikaya dosis 2 g.100 $\mathrm{g}^{-1}$ biji kedelai 
dengan jumlah keturunan $C$. analis sebanyak 21,50 ekor dan berbeda nyata dengan dosis tepung biji srikaya lainnya. Hal ini diduga karena rendahnya dosis tepung biji srikaya yang diaplikasikan, sehingga senyawa asetogenin yang terkandung dalam biji srikaya juga rendah, sesuai dengan Rustam et.al (2016) bahwa kandungan bahan aktif yang rendah dapat menyebabkan daya racun dan mortalitas yang terjadi juga rendah, sehingga jumlah keturunan akan semakin banyak. Pemberian tepung biji srikaya dengan dosis 0 g.100 g $\mathrm{g}^{-1}$ biji kedelai menyebabkan jumlah keturunan hama C.analis rata-rata sebanyak 101,50 ekor dan berbeda nyata dengan dosis lainnya, disebabkan karena tidak adanya senyawa asetogenin yang terkandung dalam tepung biji srikaya, sehingga jumlah keturunan C. analis banyak.

\section{Penyusutan Berat Biji Kedelai (\%)}

Hasil rata-rata penyusutan berat biji kedelai setelah dilakukan uji BNJ pada taraf 5\% dapat dilihat pada Tabel 5 .

Tabel 5. Rata-rata Penyusutan Berat Biji Kedelai Setelah Pemberian Beberapa Dosis Tepung Biji Srikaya.

\begin{tabular}{cc}
\hline $\begin{array}{c}\text { Dosis tepung biji } \\
\text { srikaya }\end{array}$ & $\begin{array}{c}\text { Penyusutan berat biji kedelai } \\
(\%)\end{array}$ \\
\hline 0 g. $100 \mathrm{~g}^{-1}$ & $5,55 \mathrm{a}$ \\
2 g. $100 \mathrm{~g}^{-1}$ & $2,20 \mathrm{~b}$ \\
4 g. $100 \mathrm{~g}^{-1}$ & $1,93 \mathrm{bc}$ \\
6 g. $100 \mathrm{~g}^{-1}$ & $1,83 \mathrm{bc}$ \\
8 g. $100 \mathrm{~g}^{-1}$ & $1,43 \mathrm{~cd}$ \\
10 g. $100 \mathrm{~g}^{-1}$ & $1,03 \mathrm{~d}$ \\
\hline
\end{tabular}

Tabel 5 menunjukkan bahwa pemberian tepung biji srikaya mampu menurunkan penyusutan berat biji kacang kedelai. Pemberian tepung biji srikaya dosis 10 g.100 $\mathrm{g}^{-1}$ biji kedelai menyebabkan penyusutan berat biji kedelai paling rendah yaitu sebesar $1,03 \%$ berbeda tidak nyata dengan dosis 8 g. $100 \mathrm{~g}^{-1}$ biji kedelai yaitu sebesar $1,43 \%$ dan berbeda nyata dengan dosis 6 g. $100 \mathrm{~g}^{-1}, 4$ g. $100 \mathrm{~g}^{-1}, 2$ g. $100 \mathrm{~g}^{-1}$ dan 0 g. $100 \mathrm{~g}^{-1}$ dengan penyusutan berat biji kedelai masing-masing yaitu sebesar $1,83 \%, 1,93 \%, 2,20 \%$ dan $5,55 \%$.

Pemberian tepung biji srikaya dosis 8 g.100 $\mathrm{g}^{-1}$ biji kedelai berbeda tidak nyata dengan dosis 10 g. $100 \mathrm{~g}^{-1}, 6 \mathrm{~g} .100 \mathrm{~g}^{-1}$ dan $4 \mathrm{~g}$. $100 \mathrm{~g}^{-1}$ biji kedelai dan berbeda nyata dengan dosis 2 g.100 g ${ }^{-1}$ dan 0 g.100 g $\mathrm{g}^{-1}$ biji kedelai. Pemberian tepung biji srikaya dosis $6 \mathrm{~g} .100 \mathrm{~g}^{-1}$ dan 4 g. $100 \mathrm{~g}^{-1}$ biji kedelai berbeda tidak nyata dengan dosis 8 g. $100 \mathrm{~g}^{-1}$ dan 2 g. $100 \mathrm{~g}^{-1}$ biji kedelai, namun berbeda nyata dengan dosis 10 g.100 g $\mathrm{g}^{-1}$ dan 0 g.100 g $\mathrm{g}^{-1}$ biji kedelai. Pemberia tepung biji srikaya dosis 2 g. $100 \mathrm{~g}^{-1}$ biji kedelai berbeda tidak nyata dengan dosis 6 g.100 g $\mathrm{g}^{-1}$ dan 4 g. $100 \mathrm{~g}^{-1}$ biji kedelai, namun berbeda nayata dengan dosis 10 g. $100 \mathrm{~g}^{-1}, 8$ g. $100 \mathrm{~g}^{-1}$ dan 0 g. $100 \mathrm{~g}^{-1}$ biji kedelai.

Hasil pengamatan menunjukkan bahwa semakin tinggi dosis tepung biji srikaya yang diberikan, maka semakin rendah persentase penyusutan berat biji kedelai. Berkaitan dengan jumlah keturunan $C$. analis yang dihasilkan, semakin sedikit jumlah keturunan yang dihasilkan maka aktivitas makan akan menjadi berkurang, sehingga akan mengurangi tingkat kerusakan dan penyusutan berat biji kacang kedelai akan semakin rendah. Harinta et.al (2016) menyatakan bahwa persentase kerusakan biji kacang-kacangan akibat serangan $C$. analis semakin rendah dengan semakin rendahnya tingkat populasi, rendahnya persentase kerusakan biji akan memperkecil penyusutan bobot biji. Sesuai dengan pernyataan Soekarna (1982), bahwa besarnya kerusakan dan penyusutan bobot biji ditempat penyimpanan tergantung dari tinggi rendahnya kepadatan populasi serangga, padapopulasi yang semakin padat, kerusakan dan penyusutan bobot biji semakin meningkat.

\section{KESIMPULAN}

\section{Kesimpulan}

Hasil penelitian keefektifan dosis tepung biji srikaya (Annona squamosa L.) dalam mengendalikan hama bubuk kedelai (Callosobruchus analis F.) di penyimpanan, diperoleh kesimpulan bahwa pemberian tepung biji srikaya dengan dosis 4 g.100 $\mathrm{g}^{-1}$ biji kedelai efektif mengendalikan Callosobruchus analis F. dengan waktu awal kematian 14,50 jam, Lethal time 50 selama 34 jam, mortalitas harian $32,5 \%$, mortalitas total $80 \%$, jumlah keturunan 19,25 ekor dan penyusutan berat biji kedelai $1,93 \%$.

\section{Saran}

Mengendalikan hama Callosobruchus analis F. pada biji kedelai disarankan menggunakan dosis tepung biji srikaya 4 g.100 $\mathrm{g}^{-1}$ biji kedelai. 


\section{DAFTAR PUSTAKA}

Adnyana, I. G. S., K. Sumiartha dan I. P. Sudiarta. 2012. Efikasi Pestisida Nabati Minyak Atsiri Tanaman Tropis terhadap Mortalitas Ulat Bulu Gempinis. Jurnal Agroteknologi Tropika, 1(1): 1-11.

Badan Pusat Statistik Riau. 2017. Produksi Kedelai 2016-2017. BPS Riau. Riau.

Dadang dan Prijono. 2008. Insektisida Nabati. Institut Pertanian Bogor Press, Bogor.

Harinta, Y. W. 2009. Efektifitas Bahan Non Toksik untuk Mengendalikan Kumbang Bubuk Kedelai (Callosobruchus analis F.) pada Kedelai (Glycine Max. L.). Jurnal Agrovigor, 6(2): 121-127.

Harinta, Y. W., R. Nugraheni dan A. Setyorini. 2016. Pengendalian Hama Bubuk Kedelai (Callosobruchus analis F.) dengan Biji Sirsak. Jurnal Agrin, 20(1): 81-91.

Herminanto, Nurtiati dan D. M. Kristianti. 2010. Potensi Daun Serai untuk Mengendalikan Hama Callosobruchus analis $\mathrm{F}$. pada Kedelai dalam Simpanan. Jurnal Agrovigor, 3(1): 19-27.

Kardinan, A. 2002.Pestisida Nabati: Ramuan dan Aplikasi. Penebar Swadaya, Jakarta.

Leviana, E. 2017. Toksisitas dan Kompatibilitas Ekstrak Biji Srikaya (Annona squamosa) dengan Dua Spesies Piperaceae pada Mortalitas Callosobruchus maculatus. Skripsi (Tidak Dipublikasikan). Institut Pertanian Bogor, Bogor.

Pasaribu, P. 2017. Uji Dosis Tepung Buah Sirih Hutan (Piper aduncum L.) terhadap Mortalitas Kumbang Bubuk (Sitophilus zeamais M.) pada Jagung di Penyimpanan. Skripsi (Tidak Dipublikasikan). Universitas Riau, Pekanbaru.

Purba, S. 2007. Uji Efektifitas Ekstrak Daun Mengkudu (Morinda citrifolia) terhadap Plutella xylostella L. (Lepidoptera; Plutellidae) di Laboratorium. Skripsi (Tidak Dipublikasikan). Universitas Sumatera Utara, Medan.

Putra, A. 2017. Uji Konentrasi Tepung Bunga Paitan (Tithonia diversifolia A. Gray) untuk Mengendalikan Hama Callosobruchus chinensi L. (Coleoptera:Bruchidae) pada Biji Kacang Hijau di Penyimpanan. Skripsi
(Tidak Dipublikasikan). Universitas Riau, Pekanbaru.

Rosmanto. 2016. Uji Beberapa Dosis Tepung Biji Lada Hitam (Piper nigrum L.) untuk Mengendalikan Hama Callosobruchus chinensis L. pada Biji Kacang Hijau di Penyimpanan. Skripsi (Tidak Dipublikasikan). Universitas Riau, Pekanbaru.

Rustam, R., D. Salbiah dan F. Abidin. 2016. Uji Beberapa Konsentrasi Tepung Daun Sirih Hutan (Piper aduncum L.) untuk Mengendalikan Hama Gudang Callosobruchus chinensis L. Jurnal Agrotek Trop, 5(1): 21-30.

Sinaga dan M. R. Nelly. 2010. Pengendalian Callosobruchus Chinensis (Coleoptera :Bruchidae) dengan Menggunakan Serbuk dan Ekstrak Biji Sirsak, Saga dan Bengkuang pada Benih Kacang Hijau. Universitas Sumatera Utara, Medan.

Soekarna. 1982. Serangga-serangga Gudang dan Pengendaliannya. Direktorat Perlindungan Tanaman Pangan. Bogor.

Subagiya, A. Sulistyo dan U. Nurchasanah. 2018. Toksisitas Biji Annona squamosa terhadap Kumbang Tepung (Tribolium castaneum) pada Tepung Gandum. Jurnal Agrosains, 20(1): 19-23.

Suyono. 1988. Interaksi Callosobruchus analis F.(Coleoptera:Bruchidae) dan Biji Kedelai dari Berbagai Varietas. Balai Penelitian Tanaman Pangan. Bogor.

Tarumingkeng, R. C. 1992. Insektisida: Sifat, Mekanisme Kerja dan Dampak Penggunaannya. Ukrida, Jakarta.

Wardhana, A. H., H. Amir dan J. Manurung. 2005. Efektifitas Ekstrak Biji Srikaya (Annona squamosa L.) dengan Pelarut Air, Metanol dan Heksan terhadap Mortalitas Larva Caplak Boophilus microplussecara in vitro. JITV, 10(2): 134-142.

Wowiling, J. 2010. Pestisida Nabati Mimba (Azadirachta indica A. Juss) dalam Pengendalian Organisme Pengganggu Tumbuhan (OPT). Balai Pengkajian Teknologi Pertanian Sulawesi Utara, Sulawesi Utara. 
